\title{
Validity Analysis of Ideological and Political Education in the New Period
}

\author{
Hongjie Zhang \\ Feixian Branch School, Linyi University
}

Keywords: Ideological and political education; Validity; The status quo; Countermeasures

\begin{abstract}
The effectiveness of university's ideological and political education has to be concerned by the ideological and political education workers. However, due to the influence of various factors, especially the network and globalization, the current ideological and political education work still exists the phenomenon of the lack of "validity" in some degree. This paper puts emphasis on analyzing the status quo of the current ideological and political education and the reason of validity, and it also puts forward the corresponding countermeasures of how to enhance the effectiveness of ideological and political education in universities.
\end{abstract}

\section{The Status Quo of the Effectiveness of the Ideological and Political Education in the New Period}

In the new period, the effectiveness of the ideological and political education in universities is reflected fully, which is a major aspect of the effective status quo of ideological and political education, and at the same time, there are some problems and the phenomenon of lack of "effectiveness" to a certain extent.

Reflect of the Effectiveness of the Ideological and Political Education in the New Period. To foster a large number of outstanding graduates having both ability and political integrity. After entering the 21 st century, the school education insist that talents cultivation should be the fundamental task, and educating people is fundamental, moral education is the first, the ideological and political education is also in the first place, strengthen and improve ideological and political education in order to improve the pertinence and effectiveness of ideological and political education in universities. Every university should make full use of all kinds of propaganda media, carry out various forms of ideological and political education activities, effectively improve the college students' ideological and political quality, promote the all-round development of college students. In the new period, the effective development of ideological and political education conveys a large number of the graduates of having both ability and political integrity to the great cause of socialism with Chinese characteristics, provides a strong support for our country's economic and social development.

To strengthen and improve the ideological and political education in universities.It is our party and country's good strategic significance tradition to attach great importance to the ideological and political education work. In the new period, under the background of globalization and network China's open-door to the outside world expands unceasingly, the reform of higher education deepens deeply and economy, politics of the world changes greatly, which has brought many new situations and new problems to the ideological and political education. In the face of these new situations and new problems, under the direct leadership of the CPC central committee and the state council every university actively explores new ideas, new methods of ideological and political education, which vigorously promote the effective development of ideological and political education activities, and to strengthen and improve ideological and political education itself. Ideological and political education status get further consolidate and strengthen; the content of the ideological and political education is enriched and developed; the methods of the ideological and political education is developed ; a relatively stable working group of ideological and political education is built.

The continuous development of ideological and political education theory. In the new era, the ideological and political education workers actively step into the practice of socialist modernization, 
especially the construction of ideological and political education practice, closely around the nature ,objective, tasks and priorities of the ideological and political education, and study major theoretical and practical problem of ideological and political education. They put forward a series of new ideas, publish a batch of research results on characteristic, value, principle, concept, content, methods and mechanism innovation in ideological and political education in universities, education carrier and the way of development, the ideological and political education discipline construction, ideological and political theory class teaching, the ideological characteristics of college students and the team construction of instructor and so on.

Defects in the Ideological and Political Education Effectiveness. In the new period, ideological and political education in domestic universities has made significant effect, but the work constantly adapts to the development of the new situation, and at the same time also faces more and more trouble, which leads to the phenomenon of the lack of "validity" in ideological and political education in different degrees.

Some college students' ideological and political moral quality is low. The mainstream of the contemporary college students' ideological and political moral condition is good, positive, healthy and upward. But some college students' ideological and political moral quality is low, and they present many problems, main of which are .

Dream and faith detucted. Along with the increasingly deepening of reform and development of the socialist market economy, western rotten thought culture and way of life, together with the western civilization are rolling into China, which seriously corrode the young college students. Some college students' attitude to the understanding of the "three represents" important thought is non-Marxist; Some students can't deliver the good from bad of western culture, and they worship individualism extremely abnormal; Some students don't clearly the nature of socialism with Chinese characteristics, they even deny the future of socialism; Some students have weak political consciousness under the impact of the western bourgeois ideas, their political stance is not firm, political behavior is blind and so on .

Utility color of value pursuit is strong. One reason is that the college students' learning has many mismatches. They put less emphasis on thought and theory, more on skill, less on public course and more on professional ones. Most of the students spend their spare time on English or computer etc., because these courses have strong applicability. But the course on humanistic qualities of the college students gets little attention. Under the influence of this kind of utilitarian attitude to learning, college students' cheating in the exam as well as in academic can't solved completely.

Second reason is the career choices of college students'. They par more attention on material value of their profession, such as salary, and ignore its social value. Three is in the field of college students' consumption, the phenomenon such as blind consumption, comparison consumption etc., which are very common. Four is in aspect of their opinions about love, because of the influence of market economy and modern western ideological trend, utilitarianism and randomness of love is strengthened. The love idea of "not last forever, but for once ever" is accepted by many college students, and most college students have more tolerance to the sexual behavior before marriage, unmarried cohabitation and the phenomenon of lover.

Moral consciousness is weak. At present, some college students lack of moral consciousness, they don't have social morality, their behavior is boorish, vulgar, and they don't respect for others. At the same time, with the rise and development of network, college students' moral consciousness on network should be raised.

The validity theory research of ideological and political education in universities is weak. At present, the validity theory research of the ideological and political education in universities has made some achievements, but due to the insufficient part of the effectiveness of the ideological and political education, the study of the theory of the effectiveness of ideological and political education in universities has obvious shortcomings and important research is less. Academics on the study of the theory of the ideological and political education validity problem is hard to satisfy the strengthening and improvement of ideological and political education, hard to improve its effectiveness, and also is 
hard to meet the need of promoting college students' all-round development, it should be promoted from the level of experience to the level of theoretical.

\section{The Reason Analysis of the Insufficiency of the Ideological and Political Education in the New Period}

The reason of the validity deficiency in current ideological and political education is various. The negative influence of society, the deviation of family education, the college students' lack of subject consciousness and the insufficiency of ideological and political education are the main reasons. We analyse the reasons in order to put forward targeted solutions for the enhancement of the effectiveness of the ideological and political education.

The Negative Influence of Society. Currently, many negative factors existing in the society, to a large extent, have weakened the effectiveness of the ideological and political education.

The negative effect of market economy is restricting the realization of effectiveness of the ideological and political education. The utility of the market economy makes the value of some standards and values distorted bent, the correct faith are facing stoke, which cause money worship, hedonism, extreme individualism and the bad trend gradually spread. Young college students are a group who are extremely easy to be infected by the outside world, and their "immune" to the negative effect of market economy is poorer, so ideology and value orientation of utility is gradually obvious, which adds difficulty to the ideological and political education work in the new period.

The negative impact of the Internet has weakened the effectiveness of the ideological and political education. The Internet is a "double-edged sword". It can make the transmission of information to the society fast and at the same time, it also can bring great impact on realizing the effectiveness of the ideological and political education. First, the bad information on the network brought bad influence on students' thought and behavior. Second, with the rising popularity of the network, the access to information for today's college students is more individuation, hidden, and the public opinion control of ideological and political education decline, thus which are adding the difficulty to ideological and political education work. In addition, unethical behavior on the network and the network crime also make college students' communication security deduct, real relationships difficult to exist, which will produce some psychological problems, such as suspicious, fear, prevention and even form a variety of mental illness. All of this has weakened the effectiveness of the ideological and political education to a certain extent and made the education guide increasingly weakened.

Some Ideological and Political Education Itself has Problems. At present, some universities are not fully adapt to the development of the new situation, they are lack of education target levels, the education content is lag behind, education methods are old and single, ideological and political education team is weak etc. this is the fundamental reasons of the lack of effectiveness of ideological and political education.

Part of College Students' are Lack of a Clear Subject Consciousness. Due to the long-term effects of the traditional ideological and political education and the ignorance of students' subjective initiative during practical education, not all the students are able to have a clear, conscious understanding of acceptance the activities of ideological and political education. many students are still a lack of clear consciousness of subject. Under the negative influence of the tide of market economy, young college students make a wrong choice and valuation of the ideological and political education according to their mindset and behavior habits, because of the influence of utilitarianism and pragmatism. They made a conclusion that the ideological and political education is "little value" or "useless" for their own development. This can make students are short of power of ideological and political education, and lack of a kind of need and wishes for their own development. The college students are not active to receive education, but passive to be educated. Some college students inevitably produce indifference、psychological inversion and resentment to ideological and political education under the condition of the lack of subject consciousness. Thus it adds difficulty to the ideological and political education, and it also influence and restrict the realization of effectiveness. 
The Deviation of Some Family Education. Deviation existing in the current college students' family education is weakening the effectiveness of ideological and political education in universities. The concrete expressions are: in some parents mind if they send children to college, that is to send them to the safe of "talent", the colleges will make them useful persons naturally. so the parents ignore the education of their children's ideology, economy and action. All of this increases the difficulty of the ideological and political education. Some family education lays more stress on intellectual education and less on the guidance and education of other aspects. This kind of utilitarian education is easy to cause one-sided and deforming development of college students, at the same time it also can make college students ignore the training and improving of the ideological and political education. They think it is not necessary to accept the ideological and political education. In addition, some parents require students to observe the socialist ideological and ethical norms only verbally, but not play a role model in action for college students, and they even does something immoral or illegal. So the actions reduce the effectiveness of the ideological and political education in large part.

\section{To Enhance the Effective Countermeasure of Ideological and Political Education}

It is a complex and difficult work to do the job of ideological and political education well. for the reasons for above problems, we should renew the idea, take effective measures on the basis of the inheritance and development, we should begin from the following aspects to increase the effectiveness of the ideological and political education.

Promote the Innovation of Ideological and Political Education. Innovation is the request of the ages. Only keep pace with The Times, continuous innovation can really enhance the effectiveness of the ideological and political education.

The innovation of concept. Facing the new situation we should innovate the education concept if we want to grasp the direction of the ideological and political education innovation. At present the higher education in our country has a trend of internationalization, networking, lifelong and popularization. The higher education is transferring from the edge of the economic society to the center of the society. The innovation of the ideological and political education concept is based on the judgment of the trend in the development of higher education, and the reflections on the traditional education. The concept of the current ideological and political education innovation is to set up humanistic ideas, open and harmonious idea, etc.

The innovation of content. With the expansion of the reform and opening up, the increasingly improvement of the system of socialist market economy and the rapid development of information technology, college students' learning content and life style have changed a lot. because new thoughts, new ideas and new information emerge in endlessly, the ideological and political educators in colleges and universities should actively face the new situation and new problems, advance with The Times, innovate continuously, combined with the social reality and adapt to the needs of the development of college students, update the old contents and absorb new rational content under the premise of basic stable content in order to promote the continuous improvement of the ideological and political education content system.

The innovation of methods. Methods innovation is the key to the ideological and political education innovation. Comrade Deng Xiaoping had explicitly pointed out: "the fundamental task and content of our political work does not change, our fine tradition still exists. But the time is different, conditions are different and the object is different. Therefore, the solution is also different." With the change of social environment and the development of college students thought, new situations and new problems appear constantly, the method of ideological and political education must also continue to innovate to adapt to the needs of the development of era.

To Strengthen the Party Leadership of Ideological and Political Education. Strengthen and improve the party leadership of ideological and political education. Do the jobs of ideological and political education work well, cultivate the all-round development college students who are qualified builders and reliable successors of socialism, the key lies in the Party. "In order to do jobs of 
ideological and political well, we also call for improving the party's leadership, improving the leadership of the party system", which provide strong backing for the effectiveness of the ideological and political education in colleges and universities.

To establish and improve the leading system of ideological and political education. In terms of ideological and political education in colleges and universities, universities should establish and perfect the leadership system and working mechanism of unified leadership of party committees, party and government working closely, students' self education.

To Strengthen the Team Construction of Ideological and Political Education. Ideological and political educators in colleges and universities are the organizers, planners, practitioners and regulators of the ideological and political education activities; they occupy the dominant position and play a leading role in the process of ideological and political education. Team construction of ideological and political education is connected to the success of the ideological and political education and the development of a new situation. Therefore, colleges and universities should attach great importance to the selection and cultivation and use of ideological and political education team, and fully arouse their working enthusiasm, initiative and creativity, so as to provide guarantee for enhancing the effectiveness of ideological and political education in colleges and universities.

To Bring College Students' Subjective Initiative into Full Play. In ideological and political education activity, educator and the educatee have the bidirectional interaction. Educatee as well as educator has thinking, independent and practical ability, and both of them have the subjective initiative. If educatee can give subjective initiative full play or not, which is one of the important factors of influence on the effectiveness of ideological and political education. Therefore, to realize the effectiveness of the ideological and political education, ideological and political educators' enthusiasm is not enough; we must pay attention to the full play of the college students' subjective initiative. The more abundant the subjective initiative of college students play, the ideological and political education activities will be more active and have more results.

To Optimize the Environment of Ideological and Political Education. Good environment can provide favorable conditions for ideological and political education .Therefore, to enhance the effectiveness of the ideological and political education, it is necessary to optimize the environment of ideological and political education, to strive to create a good ideological and political education environment which make social environment change appropriate to the student's growth needs.

\section{References}

[1] Shen Zhuanghai Validity analysis of Ideological and political education[M],Wuhan: Wuhan university press 2001:1

[2] Chen Min The validity connotation and evaluation basis of the ideological and political education [J]. The study on ideological and political education 2005(5):39

[3] Cui Dongyun Some ideas on the construction of harmonious campus in colleges and universities[J]. Party construction and ideological education in school.2005(9):64

[4] Omnibus volume of Deng Xiaoping 2 [M].Peking People's publishing house1994: 104

[5] Liang Jinxia, Bao Jinling The investigation report on the status quo of political education work among current university student $[\mathrm{J}]$. Journal of national institute of education administration2005 (2) : 7

[6] Omnibus volume of Jiang Zemin 2[M]. Peking People's publishing house 2006:332.

[7] He Bin Analysis on characteristics of ideological and political education during the period of social transformation [J]. Exploration of higher education2001(2):55

[8] Chen Zhanan, Lin Xiaozhe Reflection on increasing scientific content in the politics theory teaching [J]. Party construction and ideological education in schools 2005(6):18 
[9] Yang Xiaohui College students' religious beliefs and countermeasures of moral education [J].Studies in Ideological Education2006(12):19

[10]Lin Peiyun, Cai Maohua, Chen Xiongfeng College counselor team construction[J]. Literature education and profession2007(2):48 